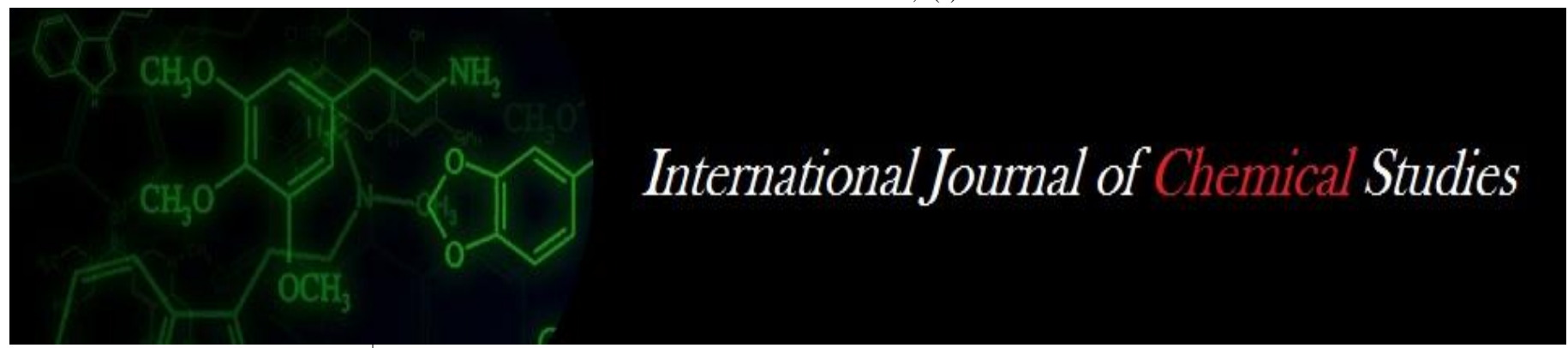

P-ISSN: 2349-8528

E-ISSN: 2321-4902

www.chemijournal.com

IJCS 2020; 8(4): 2827-2830

(C) 2020 IJCS

Received: 01-05-2020

Accepted: 03-06-2020

Nikita Mishra

Soil \& Water Engineering,

College of Agricultural

Engineering Pusa Samastipur,

Bihar, India

Yogendra Kumar Jyoti Soil \& Water Engineering, College of Agricultural

Engineering Pusa Samastipur,

Bihar, India

Indu Bhusan Bhagat

Soil \& Water Engineering,

College of Agricultural

Engineering Pusa Samastipur, Bihar, India
Corresponding Author: Nikita Mishra

Soil \& Water Engineering, College of Agricultural

Engineering Pusa Samastipur,

Bihar, India

\section{A study on the impact of water hammering on operating characteristics of hydraulic ram pump}

\author{
Nikita Mishra, Yogendra Kumar Jyoti and Indu Bhusan Bhagat
}

DOI: $\underline{\text { https://doi.org/10.22271/chemi.2020.v8.i4ah.10073 }}$

\section{Abstract}

The hydraulic Ram pump is a complete automatic device that uses the energy in the flowing water such as spring, stream or river to pump part of the water to a height above that of the source. With a continuous flow of water a hydram operates continuously with no external energy source. The delivery head of hydraulic ram ranged from $7.03 \mathrm{~m}$ to $35.16 \mathrm{~m}$ for a pressure range of 0.703 to $3.52 \mathrm{~kg} / \mathrm{cm}^{2}$. Hydraulic ram has a maximum efficiency of D' Aubussion's efficiency and Rankine's efficiency 56.26\% and $52.77 \%$ and a minimum efficiency of D' Aubussion's efficiency and Rankine's efficiency of 48.56\% and $42.45 \%$. characteristic curves of hydraulic ram working under conditions of constant waste valve lift, constant supply head and varying delivery head. With increase of delivery head the number of impulse frequency beats increases.

Keywords: Hydram, efficiency, no of stroke, discharge of waste water, discharge of useful water

\section{Introduction}

The hydraulic ram pump is a simple durable pump that can be used to deliver water from one source to another. The pump has the following characteristics flow, drive that is how much water is available to run the pump; drive head is the drop from the water level in the drive tank to the pump; delivery flow is the amount of water flowing into the delivery tank while the delivery head is the height from the pump up to the delivery tank. The normal operation range of this pump is 0.5 to 10 litres/minute. The ram pumps are durable and either made from iron casting or welded steel pipe. The readily available local materials have been used to build the pump. No electricity or any power fuel is required to run the pump, therefore, it is less expensive to own and operate.

The hydraulic Ram pump is a complete automatic device that uses the energy in the flowing water such as spring, stream or river to pump part of the water to a height above that of the source. With a continuous flow of water a hydram operates continuously with no external energy source.

\section{Working Principle}

Hydraulic ram pump works on the principle of water hammering action. The water is caught by the spring catchment (or the stream catchment) and driven to the header tank by the feed pipe. The spring or stream catchment is the first barrier to prevent organic matters to enter in the system and to reduce the efficiency of the system. The header tank allows a continuous flow to the drive pipe and the pump and it the last barer to prevent sediments to enter in the pump. The drive pipe is made from galvanized iron (G.I.). It has to support the water hammer effect which is running continuously. The drive pipe is designed to conduct water as fast as possible to the pump and it must be straight.

The Hydram is the most critical infrastructure of the system. The Hydram is attached to the pump basement. It has to absorb the shocks of the water hammer effect. The pump basement has to be carefully design because it is subject to the fatigue of the water hammer effect and is very difficult to maintain without stopping the pump from running. The delivery pipe conducts the water from the pump to the storage tank. The storage tank is used to hold water before it is delivered to communities. 


\section{Material and Methods \\ Experimental Set-up}

The present study "performance evaluation of hydraulic ram pump at different operating conditions" was conducted in Hydraulics Laboratory, Department of Irrigation and Drainage Engineering, CAE, Pusa which is located in Samastipur district of Bihar on southern and western bank of river Budhi Gandak at $25^{\circ} 59 \mathrm{~N}$ latitude and $85^{\circ} 48 \mathrm{E}$ longitude . Altitude of the site is $52.92 \mathrm{~m}$ above of mean sea level.

\section{Hydraulic Ram Pump}

The hydraulic ram pump (hydram) is an alternative pumping device that is relatively simple technology that uses renewable energy, and is durable. The hydram has only to moving parts and can be easily maintained. A hydraulic ram is a pump that uses energy from a falling quantity of water to pump some of it to an elevation much higher than the original level at the source. No other energy is required and as long as there is a continuous flow of falling water, the pump will work continuously and automatically.

It includes the procedure for the performance evaluation of the hydraulic ram pump under different operations conditions. The experimental setup consists of a Hydraulic ram having a cylindrical air vessel connected to a small rectangular chamber through a non returning valve. A waste valve is also provided in the rectangular chamber to discharge the excessive water to the collecting tank. The chamber is connected to an elevated supply tank. A delivery pipe is connected to the foot of air chamber to deliver the water to collecting tank to measure the discharge delivered by the ram. The experimental setup consists of a Hydraulic ram having a cylindrical air vessel connected to a small rectangular chamber through a non returning valve. A waste valve is also provided in the rectangular chamber to discharge the excessive water to the collecting tank. The chamber is connected to an elevated supply tank. A delivery pipe is connected to the foot of air chamber to deliver the water to collecting tank to measure the discharge delivered by the ram.

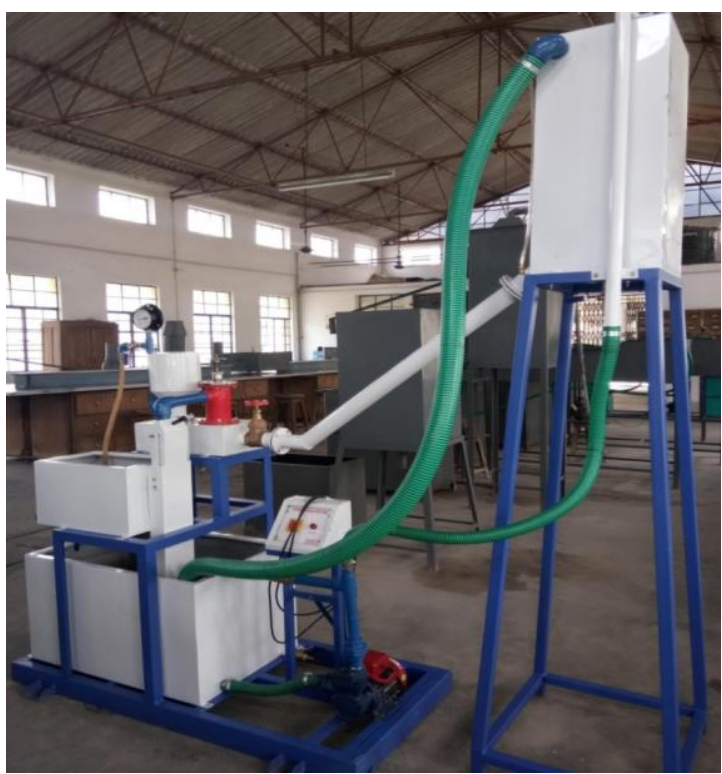

Plate 1: General view of the Hydraulic Ram Pump at Experimental site

\section{Performance Evaluation of Hydraulic Ram Pump}

Following parameters under different operating conditions were considered for performance evaluation of hydraulic ram pump:
Supply head and delivery head

Supply head is the depth of water in supply tank from its bottom (i.e. from the centre line of the pump) to the top level of water in the supply tank. It was kept $1.4 \mathrm{~m}$ throughout the experiment.

Delivery head is the elevation of water from the centre line of discharge valve to the level of water in the destination tank. It was measured by pressure gauge which is actually the pressure of water in air vessel as:

$\mathrm{h}_{\mathrm{d}}=10 \times \mathrm{P}, \mathrm{m}$ of water

Where,

$\mathrm{P}=$ pressure gauge reading, $\mathrm{kg} / \mathrm{cm}^{2}(\mathrm{psi})$

\section{Calculation of Waste Water and Useful Water}

Discharge is the volumetric flow rate of water that is transported through a given cross sectional area i.e. The amount of fluid passing a section of steam in unit time is called the discharge.

1. For discharge of waste water:

$\mathrm{R}=\frac{\mathrm{R}_{2}-\mathrm{R}_{1}}{100}$

Where

$\mathrm{R}=$ rise of water level in measuring tank in time $\left(\Delta \mathrm{t}=\mathrm{t}_{2}-\mathrm{t}_{1}\right)$, $\mathrm{cm}$

$\mathrm{R}_{1}=$ initial level of water in measuring tank at time $\mathrm{t}_{1}, \mathrm{~cm}$

$\mathrm{R}_{2}=$ final level of water in measuring tank at time $t_{2}, \mathrm{~cm}$

$\mathrm{Q}=\frac{\mathrm{R} \times \mathrm{A}}{\Delta \mathrm{t}}$

Where,

$\mathrm{Q}=$ discharge of waste water, $\mathrm{m}^{3} / \mathrm{sec}$.

$\mathrm{R}=$ rise in water level of water in measuring tank of waste water, $\mathrm{m}$

$\mathrm{A}=$ area of measuring tank $(0.42 \mathrm{~m} \times 0.289 \mathrm{~m})$

$\Delta \mathrm{t}=$ time taken for $\mathrm{R}$, sec

2. For discharge of useful water:

$r=\frac{r_{2}-r_{1}}{100}$

Where,

$\mathrm{r}=$ rise of water level in time $\Delta \mathrm{t}\left(\Delta \mathrm{t}=\mathrm{t}_{2}-\mathrm{t}_{1}\right), \mathrm{cm}$

$r_{1}=$ initial level of water in measuring tank at time $t_{1}, \mathrm{~cm}$

$r_{2}=$ final level of water in measuring tank at time $t_{2}, \mathrm{~cm}$

$\mathrm{q}=\frac{\mathrm{AXr}}{\Delta \mathrm{t}}$

Where,

$\mathrm{q}=$ discharge of useful water, $\mathrm{m}^{3} / \mathrm{sec}$

$\Delta \mathrm{t}=$ time taken for collecting useful water(r), sec

\section{Efficiency of Hydraulic Ram Pump}

The efficiency of a hydraulic ram may be expressed in two ways. The first expression, known as D' Aubuisson's efficiency ratio, gives the efficiency as the ratio of input energy of ram and its output energy. The second expression, Rankine' s efficiency ratio. 


\section{D' Aubuisson's efficiency}

$\eta_{\mathrm{a}}=\frac{\mathrm{qh}_{\mathrm{d}}}{(\mathrm{Q}+\mathrm{q}) \mathrm{h}_{\mathrm{s}}} \times 100$

\section{Rankine's Efficiency}

$\eta_{\mathrm{r}}=\frac{\mathrm{q}\left(\mathrm{h}_{\mathrm{d}}-\mathrm{h}_{\mathrm{s}}\right)}{\mathrm{Qh}_{\mathrm{s}}} \times 100$

Where,

$\eta_{\mathrm{a}}=$ D' Aubuisson's efficiency of hydraulic ram pump, per cent $(\%)$

$\eta_{\mathrm{a}}=$ Rankine's efficiency of hydraulic ram, per cent (\%)

$\mathrm{h}_{\mathrm{s}}=$ height of water in supply tank, $\mathrm{m}$ $\mathrm{h}_{\mathrm{d}}=$ delivery head, $\mathrm{m}$

$\mathrm{Q}=$ discharge of waste water, $\mathrm{m}^{3} / \mathrm{s}$

$\mathrm{q}=$ discharge of useful water lifted up, $\mathrm{m}^{3} / \mathrm{s}$

\section{Results and Discussion}

Head Discharge Relationship

The discharge (waste water discharge and useful water discharge) obtained from hydraulic ram pump was found to be affected by the delivery head. Although the supply head was kept fixed to 1.4 metre throughout the experiment but delivery head were varying as per operating conditions. Delivery head-discharge data at different operating pressures is presented in Table 1 and Fig. 1. The delivery head of hydraulic ram ranged from $7.03 \mathrm{~m}$ to $35.16 \mathrm{~m}$ for a pressure range of 0.703 to $3.52 \mathrm{~kg} / \mathrm{cm}^{2}$

Table 1: Effect of head and impulse valve frequency on discharge of hydraulic ram pump

\begin{tabular}{|c|c|c|c|c|c|}
\hline \begin{tabular}{|c|} 
Pressure \\
psi $\left(\mathbf{k g} / \mathbf{c m}^{2}\right)$
\end{tabular} & \begin{tabular}{|c|} 
Delivery head \\
$\mathbf{h}_{d}(\mathbf{m})$
\end{tabular} & $\begin{array}{c}\text { Discharge of waste water } \\
\left.(\mathrm{Q})\left(10^{-4}\right) \mathrm{m}^{3} / \mathrm{s}\right)\end{array}$ & \begin{tabular}{|c|}
$\begin{array}{c}\text { Discharge of useful water } \\
\left.(\mathrm{q})\left(10^{-4}\right) \mathrm{m}^{3} / \mathrm{s}\right)\end{array}$ \\
\end{tabular} & \begin{tabular}{|c|} 
Total discharge \\
$(\mathrm{Q}+\mathrm{q})\left(\mathbf{1 0}^{-4}\right) \mathbf{~ m}^{3} / \mathrm{s}$ \\
\end{tabular} & $\begin{array}{c}\text { Number of impulse } \\
\text { valve frequency }\end{array}$ \\
\hline $1(0.71)$ & 7.032 & 13.30 & 26.23 & 39.53 & 68 \\
\hline $2(1.41)$ & 14.064 & 24.30 & 33.40 & 57.70 & 70 \\
\hline $3(2.11)$ & 21.096 & 31.90 & 46.50 & 78.4 & 72 \\
\hline $4(2.82)$ & 28.128 & 33.90 & 57.30 & 91.2 & 75 \\
\hline $5(3.52)$ & 35.16 & 34.30 & 66.80 & 101.1 & 78 \\
\hline
\end{tabular}

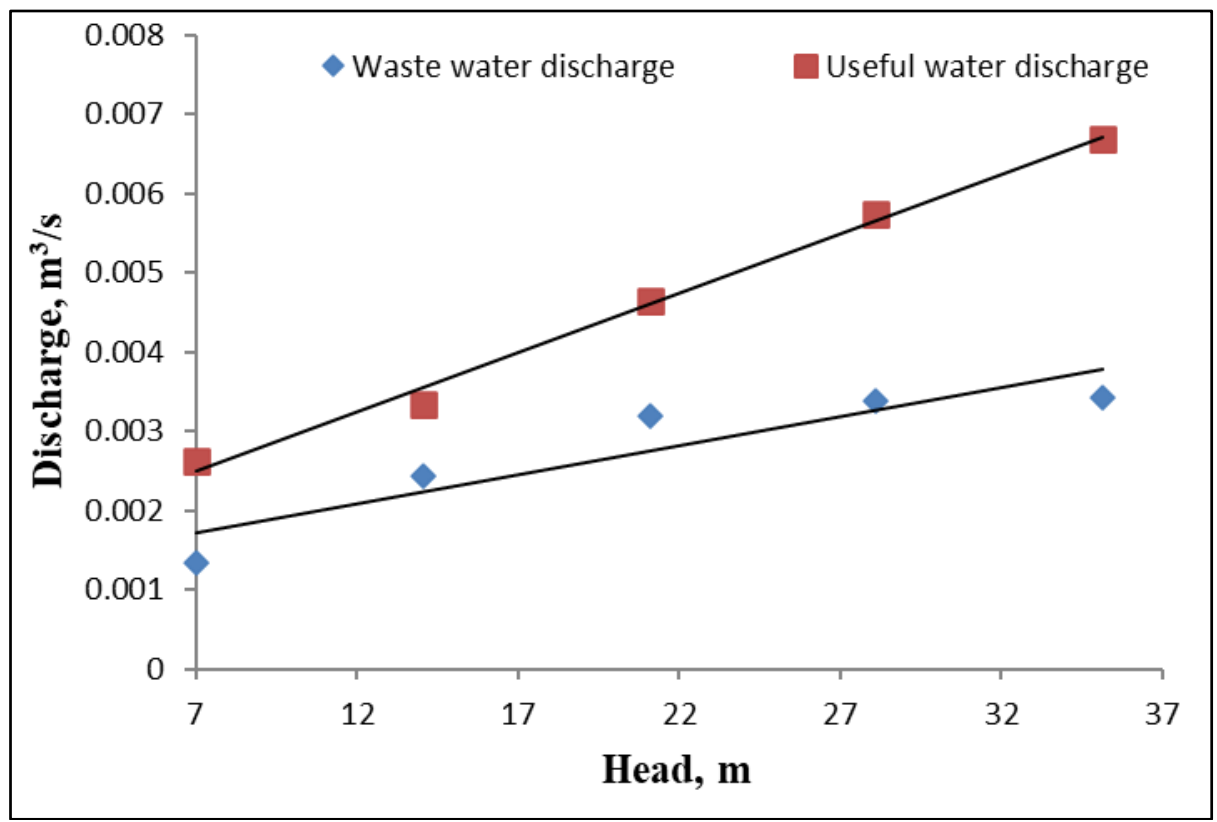

Fig 1: Variation of waste water and useful water discharge with head

\section{Efficiency of Hydraulic Ram Pump}

Efficiency of hydraulic ram pump is the ratio of energy delivered to ram and energy supplied by the ram. Efficiency directly related to flow ratio and head ratio. Efficiency by the hydraulic ram pump measured under different operating pressure. The Rankine's efficiency ranges from 42.45 to $52.77 \%$ and D' Aubuisson's efficiency ranges from 48.56 to $56.26 \%$ for a pressure range of 0.7032 to $3.52 \mathrm{~kg} / \mathrm{cm}^{2}$ respectively as shown in the figure 2 and table 2 .

Table 2: Effect of delivery head on hydraulic ram pump efficiency

\begin{tabular}{|c|c|c|}
\hline Delivery head, $\mathbf{h}_{\mathbf{d}}(\mathbf{m})$ & Rankine's Efficiency, $\boldsymbol{\eta}_{\mathbf{r}}(\boldsymbol{\%})$ & D' Aubussion's Efficiency, $\boldsymbol{\eta}_{\mathbf{a}}(\boldsymbol{\%})$ \\
\hline 7.032 & 52.77 & 56.26 \\
\hline 14.064 & 51.26 & 54.71 \\
\hline 21.096 & 50.76 & 54.20 \\
\hline 28.128 & 49.55 & 53.68 \\
\hline 35.16 & 42.45 & 48.56 \\
\hline
\end{tabular}




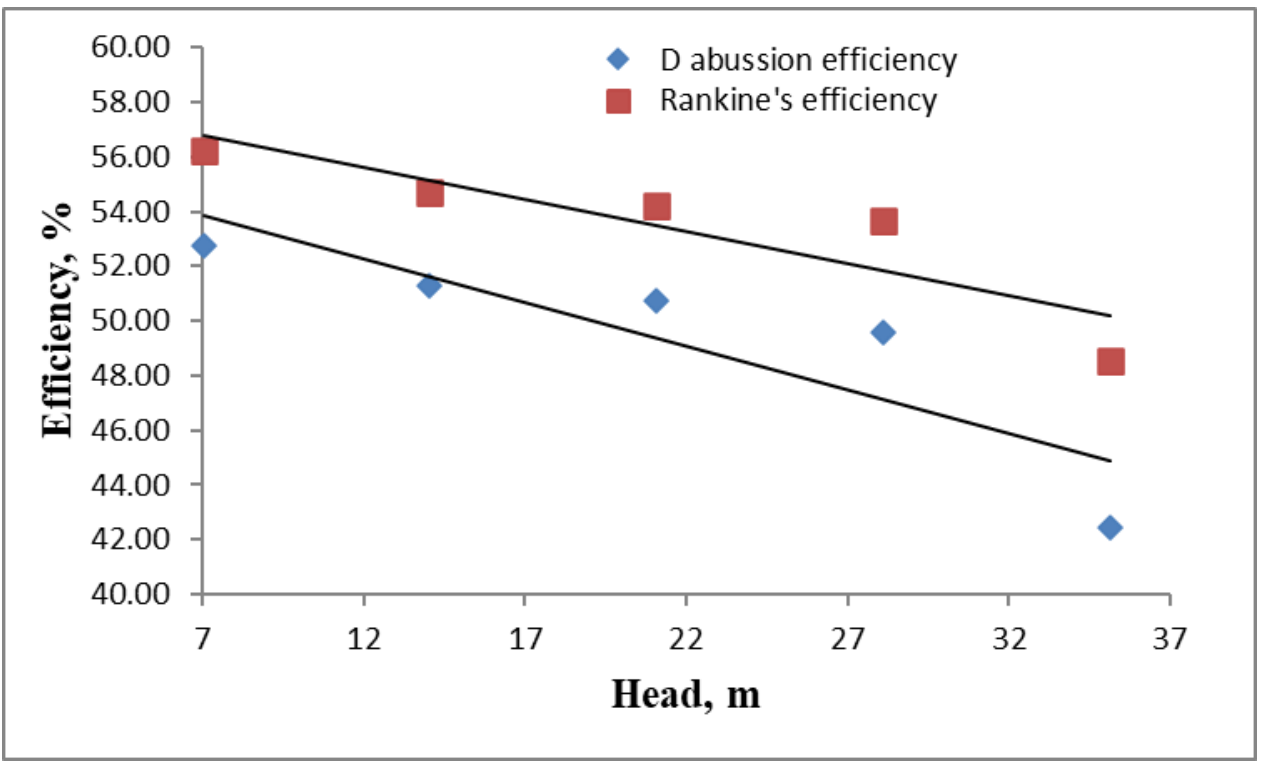

Fig 2: Variation of efficiency with delivery head

\section{No. of strokes of hydraulic ram pump}

No of stroke means that no of beats per minute. How many times the diaphragm moving top to bottom in 1 minute. No. strokes of the hydraulic ram pump measured under different operating pressure. No. of strokes ranged from 68 to 78 for a pressure range of 0.7032 to $3.52 \mathrm{~kg} / \mathrm{cm}^{2}$ respectively. No. of strokes increases with increase in operating pressure.

Table 3: No. of strokes at different operating pressure

\begin{tabular}{|c|c|}
\hline $\begin{array}{c}\text { Air vessel Pressure, PSI } \\
\left(\mathbf{k g} / \mathbf{c m}^{2}\right)\end{array}$ & No of stroke/minute \\
\hline $1(0.703)$ & 68 \\
\hline $2(1.410)$ & 70 \\
\hline $3(2.110)$ & 72 \\
\hline $4(2.820)$ & 75 \\
\hline $5(3.520)$ & 78 \\
\hline
\end{tabular}

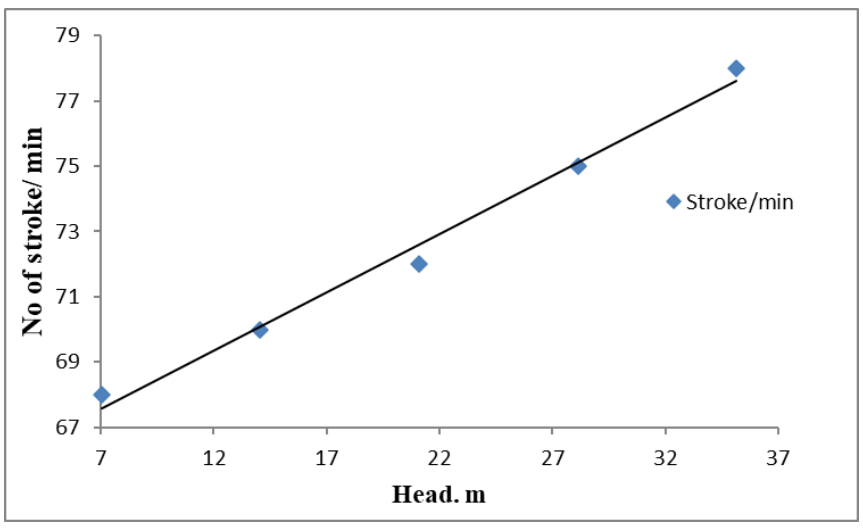

Fig 3: Variation of no. of strokes per minute with head

\section{Conclusion}

In today's world water is of a great concern to the human beings because we can't survive without it. Hydraulic ram can be one of the solutions to this problem of a mankind. Mostly in India where villages are situated far away from the water source it is not possible to the people living there to go miles away carrying away the buckets of water. There is no head loss in this experimental setup because straight length of drive pipe is $90 \mathrm{~cm}$ only so calculated loss is very less so head loss is minimized and not considered in this experiment. In the hydraulic ram pump only two moving parts so there is no wear and tear so it reduces the losses occurs in pipes.

\section{References}

1. Arnold FD, Franster AU, Benjay PP. Design and Evaluation of a Local Downdraft Hydraulic Ram Pump. ilarrdec. mmsu. edu. ph /documents / Ram_Pump_Design_Paper.pdf. 2000,1-13.

2. Balgude R, Rupanavar PS, Bagul SPDesigning of Hydraulic Ram Pump. International Journal of Engineering and Computer Science ISSN: 2319-7242. 2015; 4:11966-11971.

3. Chandra SK. Performance Evaluation of Hydraulic Ram Pump. Thesis of Training in Non government energy resources corporate research and development Bharat Heavy Electrical Limited, Hyderabad, 1983, 4-19.

4. Chi M, Diemer P. Hydraulic Ram Handbook. Zhejiang University of Technology and Dipl. Engg. Peter Diemer of BORDA. 2002, 110-111.

5. Couzinet A, Gros L, Pierrat D. Characteristics of Centrifugal Pumps Working in Direct or Reverse Mode. Hindawi Publishing Corporation International Journal of Rotating Machinery. Article ID 279049, 2013; 3:11.

6. Diwan P, Patel A, Sahu L. Design and Fabrication of Hydraulic Ram with Methods of Improving Efficiency. International Journal of Current Engineering and Scientific Research (IJCESR) ISSN (Print): 2393-8374, 2009; 3(4):5-13.

7. Gregory DJ. Hydraulic Ram Pump. North Carolina Cooperative Extension service, Publication Number: EBAE, 1996, 161-192.

8. Grandall RD. The Performance and Efficiency of Hydraulic Pumps and Motors. A Thesis of Master of Science submitted to University of Minnesota. 2010,1-3.

9. Iversen HW. An Analysis of the Hydraulic Ram. Journal of Fluids Engineering, 2010; 97(2):191-196.

10. Jeffery TD, Thomas TH, Smith AV, Glover PB, Fountain PD. Hydraulic Ram Pumps - A Guide to Ram Pumps Water Supply System. Intermediate Technology Publications ISBN: 978185331729, 1992, 144.

11. Khune S, Mehroliya S, Pathak A, Deo A. Design of Hydraulic Ram Pump. International Journal for Innovative Research in Science and Technology, ISSN: 2349-6010, 2016; 2(10):1-4. 